\title{
Ilse Lehiste (1922-2010) \\ The significance of empirical evidence in linguistics ${ }^{*}$
}

(2012)

\author{
Zita McRobbie-Utasi \\ Simon Fraser University \\ mcrobbie@sfu.ca
}

It is with immense sadness that members of the worldwide linguistics community acknowledge the passing away of Ilse Lehiste, Professor Emeritus at the Department of Linguistics, Ohio State University. Her wide-ranging scholarly legacy has greatly influenced the way linguists view the science of phonetics and its role in speech communication. Her pioneering research in employing and advancing experimental phonetic methods, together with groundbreaking theoretical works on the acoustic properties of speech sounds relevant to language, is to be considered a major contribution to the discipline of linguistics.

\section{Introduction}

Ilse Lehiste was born in Tallinn, Estonia. She received a Doctor of Philosophy degree from the University of Hamburg, Germany, in 1949; subsequently she moved to the United States, where she earned her Ph.D. in linguistics from the University of Michigan in 1959. Dr. Lehiste was a recipient of honorary doctoral degrees from the University of Essex, Great Britain (1977); the University of Lund, Sweden (1982); the University of Tartu, Estonia (1989) and the Doctor of Human Letters honorary degree from the Ohio State University (1999). Prior to her appointment at the Ohio State University in 1963, she taught at the Kansas Wesleyan University (1950-1951), at the Detroit Institute of Technology (19511956) and was a research associate at the University of Michigan's prestigious Communication Sciences Laboratory (1958-1963). Dr. Lehiste was Chair of the Department of Linguistics, Ohio State University (1965-1971) and (1985-1987), as

\footnotetext{
* I wish to acknowledge posthumously Ilse Lehiste's comments on an earlier version of this paper. Mention also must be made of Dr. Lehiste's invaluable help in compiling her academic background and scholarly output for a brief biography (McRobbie-Utasi, 2012).
} 
well as Director of the Linguistic Institute at the Ohio State University (1970). She taught as Visiting Professor at the University of Cologne, Germany (1965), University of Vienna, Austria (1974) and the University of Tokyo, Japan (1980).

In recognition of the significance of her scholarly work, Ilse Lehiste has been honored by numerous fellowships and awards: Guggenheim Fellowships (1969-1970 and 1975-1976); Center for Advanced Study in the Behavioural Sciences Fellowship, Stanford (1975-1976); Japan Society for the Promotion of Sciences Fellowship (1979-1980); Distinguished Research Award, Ohio State University (1980); Alumnae Athena Award, University of Michigan (1994); International Society of Phonetic Sciences Kay Elemetrics Award (2003); Ferdinand Johann Wiedemann Award, Republic of Estonia (2009); Fellow, The American Academy of Arts and Sciences (1990); Order of the Yugoslav Flag with Golden Wreath (1988); and Order of the White Star, $3^{\text {rd }}$ Class, Republic of Estonia (2001); and Medal for Scientific Achievement, The International Speech Communication Association (2002). Dr. Lehiste was a foreign member of two distinguished academic institutions: the Finnish Academy of Science and Letters (since 1998), and the Estonian Academy of Sciences (since 2008).

Her extensive service to the academic community includes responsibilities associated with a large number of scholarly societies, such as the Linguistic Society of America, Life member and Fellow (member of the Executive Committee, 1971-1973; President, 1980); Center for Applied Linguistics (member of the Board of Trustees, 1974-1983; Vice Chair, 1974-1979); Harvard College Board of Overseers (member of the Visiting Committee for Linguistics, 19791985); Council for the International Exchange of Scholars (member, 1977-1981); Permanent Council for the Organization of International Congress of Phonetic Sciences (member since 1989, emeritus member since 1999); Finnish Academy of Sciences Fennistics Evaluation Group (member, 1994-1996); Educational Advisory Board, John Simon Guggenheim Memorial Foundation (member, 19911999). She also served on the editorial boards of several scholarly periodicals, such as the Bibliotheca Phonetica, Journal of Phonetics and the Journal of Interdisciplinary Music Studies. Dr. Lehiste was a member of twelve scholarly associations; she served as president of the Association for the Advancement of Baltic Studies (1974-1976). She was a Fellow of the Acoustical Society of America, the American Association for the Advancement of Science, the International Society of Phonetic Sciences, and a member of the Modern Language Association, the American Association of Phonetic Sciences, the Societas Linguistica Europaea, the American Literary Translators Association, the Estonian Learned Society in America, the Finno-Ugric Studies Association of Canada, and the Société Finno-Ougrienne (corresponding member). 


\section{Scholarly Legacy}

Ilse Lehiste's remarkable scholarly output is evidenced by a large number of publications. She is author, co-author or editor of twenty books (author of nine, co-author of eight books; first author of six books), and editor or co-editor of three books. The number of articles published is 203, and her list of publications contains also 104 reviews. The impressive list of Professor Lehiste's research areas includes acoustic phonetics, prosody (suprasegmentals), phonetics and phonology, language contact, and language change. She conducted extensive research on the temporal structures of language, and on the prosody of language in relation to rhythm in spoken poetry and music. Her studies in these areas reflect thorough cross-linguistic knowledge attesting to the validity of the theories developed in her research. For example, research on the acoustic characteristics of distinctive quantity has resulted in important findings relating to Estonian; research on accentology was conducted by examining several languages, most extensively Serbo-Croatian - just to mention two well-known fields of her studies. More recently another other expansion of her research involved a survey of prosodic properties and their function in language in a number of lesser-known Finno-Ugric languages.

Dr. Lehiste successfully participated in the scholarly dialogue on a number of important issues relating to the research areas referred to above. In fact, many of her studies have been considered significant milestones serving as essential starting points for linguists pursuing research on suprasegmentals, the timing of speech, several aspects of acoustic phonetics - to name only some of the areas of her most frequently utilized findings.

The major research areas represented in her scholarly output are (i) acoustic phonetics, (ii) linguistic quantity, (iii) prosody (suprasegmentals), and (iv) language contact and language change.

\subsection{Acoustic phonetics}

Ilse Lehiste is regarded as one of the foremost authorities in acoustic phonetics. Her acoustic studies have been considered important and extensively referred to by scholars in phonetics and phonology. Among them are the books Acoustic characteristics of selected English consonants (Lehiste, 1964) and Some acoustic characteristics of dysarthric speech (Lehiste, 1965a). She was the editor of the volume Readings in acoustic phonetics (Lehiste, 1967), one of the basic handbooks 
that for decades has been widely used by students and scholars of phonetics. The contributors to this volume include leading experts, offering a wide range of topics on acoustic phonetics. The book contains three articles by Ilse Lehiste, co-authored with the prominent phonetician, Gordon E. Peterson; these are well-known classic studies, published earlier in the Journal of the Acoustical Society of America (Lehiste and Peterson,1959; Peterson and Lehiste, 1960; Lehiste and Peterson, 1961).

Some of her most influential articles on acoustic phonetics include frequently cited works such as "Vowel and speaker identification in natural and synthetic speech" (Lehiste, 1973a), "Phonetic disambiguation of syntactic ambiguity" (Lehiste, 1973b), "The perception of duration within sequences of four intervals" (Lehiste, 1979a), "Interaction between test word duration and length of utterance" (Lehiste, 1980), "Some phonetic characteristics of discourse" (Lehiste, 1982), "Signalling of the syntactic structure in whispered speech" (Lehiste, 1983a), "Duration: measurements, phonological functions, theoretical implications" (Lehiste, 1987a), "On the perception of coarticulation effects in English CVC syllables" (Lehiste and Shockey, 1972), "An instrumental study of consonant gemination" (Lehiste, Morton and Tatham, 1973), "Labeling, discrimination and repetition of stimuli with level and changing fundamental frequency" (Lehiste and Shockey, 1980).

\subsection{Linguistic Quantity}

Dr. Lehiste's substantial research focused on the clarification of the complex issues associated with Estonian phonology has significantly contributed to the understanding of the production and perception of linguistic quantity. A model of prosodic levels in the evident phonological hierarchy of segment, syllable, disyllabic foot, and word had been proposed already in an earlier article, "The function of quantity in Finnish and Estonian" (Lehiste, 1965b). It has been developed in subsequent studies and reiterated in the classic summary of research on Estonian quantity (Lehiste, 1997b). According to this model, quantity alternations can only be described by referring to units larger than the segment: that is, segmental quantity must be described by considering the syllable it occurs in and its position within the word. It does not imply, however, that segmental quantity is not relevant: the same quantity degree of the syllable can be associated with different segmental quantities which are contrastive. It has to be understood, though, that segmental quantity is not predictable on the basis of syllabic quantity. In addition to the importance of acknowledging the hierarchy of the prosodic levels 
relating to phonological quantity in Estonian, her experimental phonetic research focused on the acoustic properties of quantity has identified the relevance of (i) durational ratios, and (ii) the presence of another prosodic factor - such as, fundamental frequency - in the realization of distinctive quantity. In her frequently cited paper "Experiments with synthetic speech concerning quantity in Estonian" (Lehiste, 1975a), she reports on her experiment with synthetic stimuli administered for evaluation to a large group of listeners. The results of this classic study indicate that, although the distinction between the first and the second quantities is made on the basis of durational differences alone, the distinction between the second and third is made primarily on the basis of pitch contour, and, to a far lesser degree, duration in the second syllable - implying the perceptual significance of the fundamental frequency pattern. While her findings convincingly argue for the relevance of durational ratios within the metric foot and the significance of pitch movement, she had always been open to discuss alternate approaches to the analysis of Estonian quantity - approaches, for example, which consider accent a relevant prosodic factor in the realization of phonological quantity (Eek and Meister, 1997). In a frequently cited paper (Fox and Lehiste, 1989), considering the alternate approach - i.e., the role of accent in the realization of linguistic quantity - the authors concluded that ..."intersyllabic ratio is sufficient for discrimination between $\mathrm{Q} 3$ and Q1. In case of identical overall durations...the same judgements of ratios 2:1 and 3:2 were 96.9\%; in the case of different overall durations, ...the recognition score dropped to $82.2 \%$, which is still relatively high. In the identification of meaningful words, however, correct identification score never rose above $51 \% \ldots$ The addition of the falling contour to the first syllable of an actual word failed to provide the necessary cue for identification at a level better than chance ... thus an additional cue may be what is predicted by the accent theory". (p. 85)

Here I shall cite only some of Dr. Lehiste's numerous works dealing with Estonian quantity: "Segmental and syllabic quantity in Estonian" (Lehiste, 1960), Consonant quantity and phonological units in Estonian (Lehiste, 1966), "Search for phonetic correlates in Estonian prosody" (Lehiste, 1997b), and "The structure of trisyllabic words" (Lehiste, 1997c). 


\subsection{Prosody (suprasegmentals)}

\subsubsection{Acoustic properties and linguistic functions of suprasegmentals}

Lehiste's classic monograph Suprasegmentals (1970) provides a thorough investigation of all prosodic phenomena present in languages. The detailed discussions are appropriately illustrated from a large number of cross-linguistic examples. In addition to describing the acoustic characteristics of the suprasegmental features - duration, pitch, stress - she identifies patterns of these features relevant to their function in the phonology of the language, rendering this experimental study on suprasegmentals as an important contribution to linguistic theory. At least two of her findings deserve mention here, both of which have implications going beyond the physical description of suprasegmentals. One of her widely utilized findings is her analysis of linguistic quantity. She states that it is essential to separate instances where duration alone is responsible for the realization of phonological contrasts, from those where other prosodic factors also have to be taken into consideration to account for degree alternations relevant to the phonology of the language - Estonian quantity is a case in point here (see Section 2.2). The other finding concerns the domain of phonologically relevant suprasegmental phenomena, for there are languages where the domain of contrastive prosodics may extend beyond the segment to the syllable or the foot; examples here include degree alternations in Saami, Estonian, and Finnish.

Among her many articles dealing with various aspects of suprasegmentals, mention will be made here of two important studies: "Suprasegmental features in speech" (Lehiste, 1976) and "The many linguistic functions of duration" (Lehiste, 1984a).

\subsubsection{Temporal structures in speech}

Ilse Lehiste's research has influenced theoretical phonetics in several important areas. Her studies on boundary phenomena have resulted in findings utilized by phoneticians examining the prosodic structure of larger linguistic units, such as paragraphs and sentences. Lehiste's experiments directed to discover the relationship between the suprasegmental structure of these units and the phonetic factors relevant to the signaling of boundaries have resulted in advancing research on the understanding of such boundary phenomena as preboundary lengthening, 
presence of laryngealization and length of pause. She also studied the effects of morphological and syntactic boundaries relating to the temporal structure of utterances. Her publications on researching boundary phenomena include "Acoustic studies of boundary signals" (Lehiste, 1962), "The timing of utterances and linguistic boundaries" (Lehiste, 1972), "The role of temporal factors in the establishment of linguistic units and boundaries" (Lehiste, 1975b), "The phonetic structure of paragraphs" (Lehiste, 1975c), "Perception of sentence boundaries with and without semantic information" (Lehiste \& Wang, 1977), "Perception of sentence and paragraph boundaries" (Lehiste 1979b), and "Sentence boundaries and paragraph boundaries - perceptual evidence" (Lehiste, 1979c).

One of her most significant theoretical studies investigates the much-debated concept of isochrony. In the paper "Isochrony reconsidered" (Lehiste, 1977), she argues for isochrony - the organizing of utterances by speakers into more or less equal rhythmic units - being a perceptual phenomenon. She experimentally tested previous findings relating to constraints on production and perception of isochrony, concluding that although there is some evidence of speakers' aim at isochrony in production - manifesting in ways they handle durational constraints - it is most plausible that "the listener imposes a rhythmic structure on sequences of interstress intervals in spite of the fact that their durational differences are above the perceptual threshold." (p. 258) The article also provides an examination of the integration of isochrony in English syntax, revealing that both speakers and listeners are aware of boundary signals by the increase of the interstress interval - a fact evidencing the integration of isochrony into the grammar at the level of syntax.

\subsubsection{Metrical structures: speech, poetry and music}

Ilse Lehiste contributed significantly to research on prosody in language and poetry. The hypothesis she explored in the course of her investigation of the relationship between the prosody of a language and the metrical structure of poetry in that language was stated in the article "Rhythm of poetry, rhythm of prose" (Lehiste, 1985). According to this hypothesis, "The prosody of a language is crystallized in the prosody of poetry created in that language". (p. 145)

All of her studies relating to this research area were carried out by way of acoustic analyses of a large database taken from several languages. One of the aspects of research on prosody is concerned with the manner sung poetry accommodates phonetic constraints in the language. Results of the production and perception studies have been disseminated in the book, The temporal structure of Estonian runic songs: A study of the relationship between language and music 
(Ross and Lehiste, 2001), and in several influential articles such as "The metric structure of a recited Finnish spell" (Lehiste, 1984b), "Phonetic realization of metrical structure in some types of Estonian verse" (Lehiste, 1986), "Rhythm in spoken sentences and read poetry" (Lehiste, 1987b), "An acoustic analysis of the metrical structure of orally produced Lithuanian poetry" (Lehiste, 1990a), "Phonetic investigation of metrical structure in orally produced poetry" (Lehiste, 1990b), "The phonetics of metrics" (Lehiste, 1992), "Lost prosodic oppositions: A study of contrastive duration in Estonian funeral laments" (Ross and Lehiste, 1994), "The phonetic realization of the haiku form in Estonian poetry, compared to Japanese" (Lehiste, 1997a), "Timing in Estonian folksongs as interaction between speech prosody, meter, and musical rhythm" (Ross and Lehiste, 1998), and "Contemporary Finnish and Estonian realizations of folksongs in the Kalevala metre" (Lehiste, 2001).

\subsubsection{Prosody of lesser-known Finno-Ugric languages}

More recently Ilse Lehiste was heavily involved with an international research project aimed at surveying the prosodic structures of lesser-known Finno-Ugric languages. In this ongoing project the languages examined with her leading participation are Erzya, Meadow Mari and Livonian.

(i) Concerning Erzya prosody, the acoustic analysis of the material points to the recognition that neither fundamental frequency nor duration is distinctive in that language. Although duration may play some role in identifying a stressed syllable, further research is needed to confirm this possibility.

(ii) In Meadow Mari there is no contrastive quantity, duration being the most evident phonetic correlate of stress; it also has the additional function of signaling boundaries of higher-level grammatical units. Fundamental frequency in Meadow Mari is rising in stressed syllables, but it is sentence intonation that governs fundamental frequency contour.

(iii) With regard to the number of contrastive quantities in Livonian, the traditional two-way quantity opposition view was challenged and a ternary quantity distinction was proposed at the level of metric feet, by taking into consideration the role of durational ratios within the disyllabic unit. Further, the role of contrastive tone in Livonian was examined, resulting in the recognition that falling vs. rising 
fundamental frequencies indeed play a role in distinguishing two types of Livonian words.

It must be emphasized that this is a pioneering project, both in terms of the focus and scope of the research and the methodology employed. Further, the team of researchers were compelled to deal with numerous difficulties, such as regional variations and more importantly, the severely endangered status of some of the languages involved. The surveys of the prosody based on the sometimes scanty materials available, however, have produced important information during this relatively brief period of time, despite the complexities associated with the early stages of the research. The significance of the theoretical implications of this project to comparative Finno-Ugric prosody on the one hand and to general linguistics on the other are summarized in McRobbie-Utasi, 2010.

Publications by Ilse Lehiste relating to this project include the following studies: "The Finno-Ugric prosody project" (Lehiste, 2007), "Erzya prosody" (Lehiste et al., 2003), "Meadow Mari prosody" (Lehiste et al., 2005), "Livonian prosody" (Lehiste et al., 2008), and "Experimental study of prosody in FinnoUgric languages" (Lehiste and Pajusalu, 2010).

\subsubsection{Accentology}

Ilse Lehiste's long-time collaboration with Pavle Ivić, the distinguished scholar of South Slavic, a dialectologist and a phonologist, resulted in numerous important findings published in two books and a number of articles. Some of their early research was published in the book Accent in Serbo-Croatian. An experimental study (Lehiste and Ivić, 1963). In this study the issue of the realization of falling and rising accents in relation to the status of pitch in the following syllable was discussed. Based on the results of large-scale acoustic measurements and perception tests, the authors concluded that in order to perceive a rising accent, the following syllable has to have a pitch as high as or higher than that of the pitch in the syllable with the rising accent; the falling accent will be perceived if the pitch in the following syllable is lower, or if there is an absence of a syllable following the accented one. The role of duration of the accented syllable was also considered, and it was found that the pitch contour could be perceived in isolation if the nucleus of the accented syllable was long, but the rising and falling accents were neutralized if the accented syllable in isolation contained a short vowel. Their other book, Word and sentence prosody in Serbocroatian (Lehiste and Ivić, 1986), contains a summary of their twenty-year research on Serbo-Croatian accentuation; it presents an extensive acoustic analysis of a rich data collection, further clarifying 
the characteristics of the rising and falling accents in Serbo-Croatian. In addition to confirming their previous findings, the analysis incorporated the examination of the relationship between the realization of accents and the syllabic structure of the word on the one hand and their position in the sentence on the other. The authors also took regional variations into account in arriving at the final results.

Examining further the realization of tone in Serbo-Croatian and in two additional languages - Estonian and Swedish - Dr. Lehiste continued to identify the domain of tonal patterns. Her findings reveal the relationship between bisyllabicity and tone. In the article "Bisyllabicity and tone" (Lehiste, 2004) she convincingly argues for the connection between the prosodic structure and bisyllabicity: "In all three languages, there are no contrasts on monosyllabic words, and a disyllabic sequence is necessary for the manifestation of contrastive patterns" (p. 114).

\section{Language contact, language change}

Ilse Lehiste's interest in language contact resulted in one book and several papers. The book Lectures on language contact (Lehiste, 1988) is based on her senior and first-year graduate courses over a period of ten years. These lectures cover a wide range of topics relating to the main aspects of language contact. In addition to the concise presentation of sociolinguistic concepts such as bilingualism, pidgins and creoles, language convergence and interference, to mention here only some of the language contact phenomena, she successfully incorporated her own research into these lectures, emphasizing the importance of experimental testing of sociolinguistic theories. The book contains intriguing discussions on several topics, such as language change resulting from languages-in-contact situations, the Sprachbund concept, and comparisons of language use between monolingual and bilingual speakers, arguing for different approaches to the analysis of the bilingualism of the individual vs. bilingualism of the community. These discussions are appropriately illustrated by examples from a large number of languages. The book also offers clear and informative explanations of both the social and the linguistic consequences of language contact.

In 1979 a co-authored book based on Lehiste's teaching of historical linguistic courses was published: Principles and methods for historical linguistics (Jeffers and Lehiste, 1979). In addition to providing a thorough discussion of upto-date methodology for comparative and internal reconstructions, the authors present a meticulous survey of language change in all areas of grammar, including a chapter on the effect of language contact on language change. One of the features 
that makes this publication especially attractive for teaching is the abundance of novel examples from several languages rarely cited in historical linguistic textbooks.

Lehiste's research in language contact phenomena and historical linguistics has significantly contributed to the knowledge of language change in progress. For example, in the two articles referred to most frequently, "Polytonicity in the area surrounding the Baltic Sea" (Lehiste, 1978) and "Prosodic change in progress: Evidence from Estonian" (Lehiste, 1983b), she concluded that tonal patterns are formed in Estonian, in place of quantity degree alternations, attesting to a prosodic change in progress. She reached this conclusion by a series of acoustic analyses of quantity in Estonian, thereby confirming Jakobson's theory (1931) concerning the inclusion of Estonian in the Baltic polytonicity-Sprachbund.

\section{Conclusions}

In one of Lehiste's best-known works, Suprasegmentals (Lehiste, 1970), referred to above, she stated that "A phonologist ignores phonetics at his own peril" (p. vi). Based on the remarkable breadth and depth of her research, it may be concluded that she succeeded in defining unifying principles which enable scholars to consider the integration of speech science into the major areas of linguistic investigations; she also succeeded in elevating the discipline of phonetics to a level where it can no longer be separated from any aspects of speech communication research.

\section{References}

Eek, Arvo, and Einar Meister. (1997) Simple perception experiments on Estonian word prosody: Foot structure vs. segmental quantity. In Ilse Lehiste and Jaan Ross (eds.), Estonian prosody: Papers from a symposium (pp. 71-99). Tallinn: Institute of Estonian Language.

Fox, Robert, and Ilse Lehiste. (1989) Discrimination of duration ratios in bisyllabic tokens by native English and Estonian listeners. Journal of Phonetics 17, pp.167-174. 
Jakobson, Roman. (1931) Über die phonologischen Sprachbunde. TCLP 4. Reprinted in his Selected Writing I: Phonological Studies 1962 (pp. 137-140). The Hague: Mouton \& Co.

Jeffers, Robert J., and Ilse Lehiste. (1979) Principles and methods for historical linguistics. Cambridge, Massachusetts: MIT Press.

Lehiste, Ilse. (1960) Segmental and syllabic quantity in Estonian. American Studies in Uralic Linguistics 1, pp. 21-82.

Lehiste, Ilse. (1962) Acoustic studies of boundary signals. Proceedings of the Fourth International Congress of Phonetic Sciences, Helsinki 1961 (pp. 178187). The Hague: Mouton \& Co.

Lehiste, Ilse. (1964) Acoustic characteristics of selected English consonants.

Bloomington: Indiana University.

Lehiste, Ilse. (1965a) Some acoustic characteristics of dysarthric speech. Bibliotheca Phonetica 2. Basel: S. Krager A.G.

Lehiste, Ilse. (1965b) The function of quantity in Finnish and Estonian. Language 41(3), pp. 447-456.

Lehiste, Ilse. (1966) Consonant quantity and phonological units in Estonian. Bloomington: Indiana University.

Lehiste, Ilse. (1967) Readings in acoustic phonetics. Cambridge, Massachusetts: MIT Press.

Lehiste, Ilse. (1970) Suprasegmentals. Cambridge, Massachusetts: MIT Press.

Lehiste, Ilse. (1972) The timing of utterances and linguistic boundaries. Journal of the Acoustical Society of America 51(6), pp. 2018-2024.

Lehiste, Ilse. (1973a) Vowel and speaker identification in natural and synthetic speech. Language and Speech 16(4), pp. 356-364.

Lehiste, Ilse. (1973b) Phonetic disambiguation of syntactic ambiguity. Glossa 7(2), pp. 107-122.

Lehiste, Ilse. (1975a) Experiments with synthetic speech concerning quantity in Estonian. In V. Hallap (ed.), Congressus Tertius Internationalis FennoUgristarum Tallinnae habitus, 17-23 VIII 1970. Acta Linguistica Pars I (pp. 254-269). Tallinn: Valgus.

Lehiste, Ilse. (1975b) The role of temporal factors in the establishment of linguistic units and boundaries. In W.U. Dressler and F.-V. Mares (eds.), Phonologica 2 (pp. 115-122). München-Salzburg: Wilhelm Fink Verlag.

Lehiste, Ilse. (1975c) The phonetic structure of paragraphs. In A. Cohen and S.G. Nooteboom (eds.), Structure and process in speech perception: Proceedings of the Symposium on dynamic aspects of speech perception, I.P.O. Eindhoven, Netherlands, August 4-6, 1975 (pp. 195-203). Berlin: Springer Verlag. 
Lehiste, Ilse. (1976) Suprasegmental features in speech. In N.J. Lass (ed.), Contemporary issues in experimental phonetics (pp. 225-239). New York: Academic Press.

Lehiste, Ilse. (1977) Isochrony reconsidered. Journal of Phonetics 5, pp. 253-263. Lehiste, Ilse. (1978) Polytonicity in the area surrounding the Baltic Sea. In E. Gaeding, G. Bruce and R. Bannert (eds.), Nordic prosody: Papers from a Symposium. Travaux de l'Institut de Phonetique de Lund 13 (pp. 237-247). Lund: Department of Linguistics, Lund University.

Lehiste, Ilse. (1979a) The perception of duration within sequences of four intervals. Journal of Phonetics 7, pp. 313-316.

Lehiste, Ilse. (1979b) Perception of sentence and paragraph boundaries. In B. Lindblom and S. Öhman (eds.), Frontiers of speech research (pp. 191-202). London: Academic Press.

Lehiste, Ilse. (1979c) Sentence boundaries and paragraph boundaries - perceptual evidence. In P.R. Clyne, W.F. Hanks and C.L. Hofbauer (eds.), The elements: A parasession on linguistic units and levels (pp. 99-109). Chicago: Chicago Linguistic Society, University of Chicago.

Lehiste, Ilse. (1980) Interaction between test word duration and length of utterance. In L.R. Waugh and C.H. van Schooneveld (eds.), The melody of language (pp. 269-276). Baltimore: University Park Press.

Lehiste, Ilse. (1982) Some phonetic characteristics of discourse. Studia Linguistica 36(2), pp. 117-130.

Lehiste, Ilse. (1983a) Signalling of the syntactic structure in whispered speech. Folia Linguistica 17(1-2), pp. 239-245.

Lehiste, Ilse. (1983b) Prosodic change in progress: Evidence from Estonian. In I. Rauch and G.F. Carr (eds.), Language change (pp. 10-27). Bloomington: Indiana University Press.

Lehiste, Ilse. (1984a) The many linguistic functions of duration. In J.E. Copeland (ed.), New directions in linguistics and semiotics (pp. 96-122). Houston: Rice University Studies.

Lehiste, Ilse. (1984b) The metric structure of a recited Finnish spell. UralAltaische Jahrbücher 4, pp. 83-89.

Lehiste, Ilse. (1985) Rhythm, of poetry, rhythm of prose. In V. Fromkin (ed.), Phonetic linguistics: Essays in honor of Peter Ladefoged (pp. 145-155). Orlando: Academic Press.

Lehiste, Ilse. (1986) Phonetic realization of metrical structure in some types of Estonian verse. Ural-Altaische Jahrbücher 6, pp. 11-20.

Lehiste, Ilse. (1987a) Duration: measurements, phonological functions, theoretical implications. In Ü. Viks (ed.), Proceedings of the XIth International Congress of Phonetic Sciences, August 1-7, 1987, Tallinn, Estonia. Vol. 4 (pp. 
9-15). Tallinn: Academy of Sciences of the Estonian SSR, Institute of Language and Literature.

Lehiste, Ilse. (1987b) Rhythm in spoken sentences and read poetry. In W.U. Dressler, H.C. Luschützky, O.E. Pfeiffer and J.R. Rennison (eds.), Phonologica 1984: Proceedings of the Vth international phonology meeting, Eisenstadt, June 25-28, 1984 (pp. 165-173). London: Cambridge University Press.

Lehiste, Ilse. (1988) Lectures on language contact. Cambridge, Massachusetts: MIT Press.

Lehiste, Ilse. (1989) Current debates concerning Estonian quantity. In J. A. Nevis, (ed.), Proceedings of the sixth annual meeting of the Finno-Ugric Studies Association of Canada (pp. 77-86). Lanham, Maryland: University Press of America.

Lehiste, Ilse. (1990a) An acoustic analysis of the metrical structure of orally produced Lithuanian poetry. Journal of Baltic Studies XXI (2), pp. 145-156.

Lehiste, Ilse. (1990b) Phonetic investigation of metrical structure in orally produced poetry. Journal of Phonetics 18, pp. 123-133.

Lehiste, Ilse (1992) The phonetics of metrics. Empirical studies of the arts 10(2), pp. 95-120.

Lehiste, Ilse. (1993) Effect of pitch movement timing on perceived duration and prominence in Estonian and English listeners. In D. House and P. Touati (eds.), Proceedings of an ESCA Workshop on prosody, September 27-29, Lund, Sweden (pp. 250-253). Lund: Lund University Department of Linguistics, Working Papers (4).

Lehiste, Ilse. (1997a) The phonetic realization of the haiku form in Estonian poetry, compared to Japanese. In S. Shigeru, H. Hirose and H. Fujusaki (eds.), Speech production and language: In honor of Osamu Fujimura (pp. 241-249). Speech Research 13. Berlin: Mouton de Gruyter.

Lehiste, Ilse. (1997b) Search for phonetic correlates in Estonian prosody. In I. Lehiste and J. Ross (eds.), Estonian prosody: Papers from a symposium (pp. 11-35). Tallinn: Institute of Estonian Language.

Lehiste, Ilse. (1997c) The structure of trisyllabic words. In I. Lehiste and J. Ross (eds.), Estonian prosody: Papers from a symposium (pp. 149-164). Tallinn: Institute of Estonian Language.

Lehiste, Ilse. (2001) Contemporary Finnish and Estonian realizations of folksongs in the Kalevala metre. Linguistica Baltica 9, pp. 77-89.

Lehiste, Ilse. (2004) Bisyllabicity and tone. In B. Bel and I. Marlien (eds.), TAL 2004, Beijing. International Symposium on tonal aspects of languages (pp. 111-114). Beijing: Chinese Academy of Social Sciences. 
Lehiste, Ilse. (2007) The Finno-Ugric prosody project. Linguistica Uralica XLIII (1), pp. 1-10.

Lehiste, Ilse, Nina Aasmäe, Einar Meister, Karl Pajusalu, Pire Teras, and Tiit-Rein Viitso. (2003) Erzya prosody. Mémoires de la Société Finno-Ougrienne 245. Helsinki: The Finno-Ugrian Society.

Lehiste, Ilse, and Pavle Ivić. (1963) Accent in Serbo-Croatian. An experimental study. Ann Arbor: Michigan Slavic Materials 4.

Lehiste, Ilse, and Pavle Ivić. (1986) Word and sentence prosody in Serbocroatian. Cambridge, Massachussets: MIT Press.

Lehiste, Ilse, Katherine Morton, and Mark Tatham. (1973) An instrumental study of consonant gemination. Journal of Phonetics 1(2), pp. 131-148.

Lehiste, Ilse, and Karl Pajusalu. (2010) Experimental study of prosody in FinnoUgric languages. In Csúcs, S. (ed.), Congressus XI Internationalis FennoUgristarum Piliscsaba 9-14. VIII.2010. Pars 1. Orationes Pleanariae (pp. 225245). Budapest: Reguly Társaság.

Lehiste, Ilse, and Gordon E. Peterson. (1959) Vowel amplitude and phonemic stress in American English. Journal of the Acoustical Society of America, 31(4), pp. 428-435. Reprinted in Lehiste (1967, pp. 183-190).

Lehiste, Ilse, and Gordon E. Peterson. (1961) Transitions, glides, and diphthongs. Journal of the Acoustical Society of America, 33(3), pp. 268-277. Reprinted in Lehiste (1967, pp. 228-237).

Lehiste, Ilse, and Linda Shockey. (1972) On the perception of coarticulation effects in English CVC syllables. Journal of Speech and Hearing Research 15(3), pp. 500-506.

Lehiste, Ilse, and Linda Shockey. (1980) Labeling, discrimination and repetition of stimuli with level and changing fundamental frequency. Journal of Phonetics 8, pp. 469-474.

Lehiste, Ilse, Pire Teras, Toomas Help, Pärtel Lippus, Einar Meister, Karl Pajusalu, and Tiit-Rein Viitso. (2005) Meadow Mari prosody. Linguistica Uralica Supplementary Series, Volume 2. Tallinn: Teaduste Akadeemia Kirjastus.

Lehiste, Ilse, Pire Teras, Valts Ernštreits, Pärtel Lippus, Karl Pajusalu, Tuuli Tuisk, and Tiit-Rein Viitso. (2008) Livonian prosody. Mémoires de la Société FinnoOugrienne 255. Helsinki: The Finno-Ugrian Society.

Peterson, Gordon, E. and Ilse Lehiste. (1960) Duration of syllable nuclei in English. Journal of the Acoustical Society of America, 32(6), pp. 693-703. Reprinted in Lehiste (1967, pp. 191-201).

Lehiste, Ilse, and William Shi-Yuan Wang. (1977) Perception of sentence boundaries with and without semantic information. In W.U. Dressler and O.E. Pfeiffer (eds.), Phonologica 1976. Akten der dritten internationalen 
Phonologie-Tagung, Wien, 3.-4. September 1976 (pp. 277-283). Insbrucker Beiträge zur Sprachwissenschaft 19.

McRobbie-Utasi, Zita. (2010) Comments on Lehiste, I. and Pajusalu, K.'s paper Experimental study of prosody in Finno-Ugric languages. Congressus XI Internationalis Fenno-Ugristarum 9-14. VIII. 2010 (vol. I, pp. 247-265). Piliscsaba, Hungary: Reguly Társaság.

McRobbie-Utasi, Zita. (2012) Ilse Lehiste. The Encyclopedia of Applied Linguistics. On-line publication. Retrieved from http://www.encyclopediaofappliedlinguistics.com

Ross, Jaan, and Ilse Lehiste. (1994) Lost prosodic oppositions: A study of contrastive duration in Estonian funeral laments. Language and Speech 37(4), pp. 407-424.

Ross, Jaan, and Ilse Lehiste. (1998) Timing in Estonian folksongs as interaction between speech prosody, meter, and musical rhythm. Music perception 15(4), pp. 319-333.

Ross, Jaan, and Ilse Lehiste. (2001) The temporal structure of Estonian runic songs: A study of the relationship between language and music. Berlin: Mouton de Gruyter. 